\title{
8 \\ AL-SHABAAB AND THE HORN OF AFRICA
}

\author{
Ken Menkhaus
}

The Horn of Africa is a region plagued by crisis. Its many challenges have created conducive conditions for criminal and terrorist networks and have led to extensive international intervention. The region's troubles have produced an exceptionally difficult operating environment for its residents, governments, and external actors seeking to promote stability and development.

Today, the Somali militant group al-Shabaab remains the most dangerous terrorist organization operating in the Horn. It became an official al-Qaida affiliate in 2012, and it has conducted a number of major international terrorist attacks in the region, including in Kampala in 2010 and Nairobi in 2013 and 2019. It remains the main source of political violence in Somalia.

This chapter provides general background on the Horn of Africa but primarily focuses on Somalia due to ongoing U.S. military action against al-Shabaab. After providing an overview of the modern history of Somalia, the chapter recounts the evolution of al-Shabaab and how it gained strength in the country. It also examines the factors that have been instrumental to al-Shabaab's survival despite persistent U.S. and international opposition.

\section{Background of the Horn}

The Horn of Africa is home to hundreds of different ethno-linguistic groups. Some, such as the Oromo, number close to 40 million and are better described as nations. The region is diverse religiously, with inhabitants practicing Islam, Orthodox Christianity, Catholic and Protestant Christianity, and indigenous religions. Islam and Orthodox Christianity have existed in much of the Horn for more than 1,000 years and are deeply embedded in local culture and identity. ${ }^{1}$ For most of that history, Muslim and Christian populations generally co-existed peacefully. In more recent times, however, tensions between the region's faith groups have spiked, reflected in growing intolerance and occasional communal violence.

The region's states-Sudan, South Sudan, Ethiopia, Eritrea, Somalia, Djibouti, Uganda, and Kenyacount among the poorest and least developed in the world (see Figure 8.1). ${ }^{2}$ Most of the population lives at or near subsistence levels, and basic development indicators such as infant mortality, literacy, and life expectancy are extremely low. The region is prone to recurring humanitarian crises and even periodic famine. Pressures on the land have strained carrying capacity and have led to deforestation, degraded rangelands, desertification, and in some areas serious long-term water shortages.

Population growth and fertility rates are among the highest in the world. This contributes to pressure on education, housing, land, and employment, fueling urban drift and intensifying the Horn's high levels 


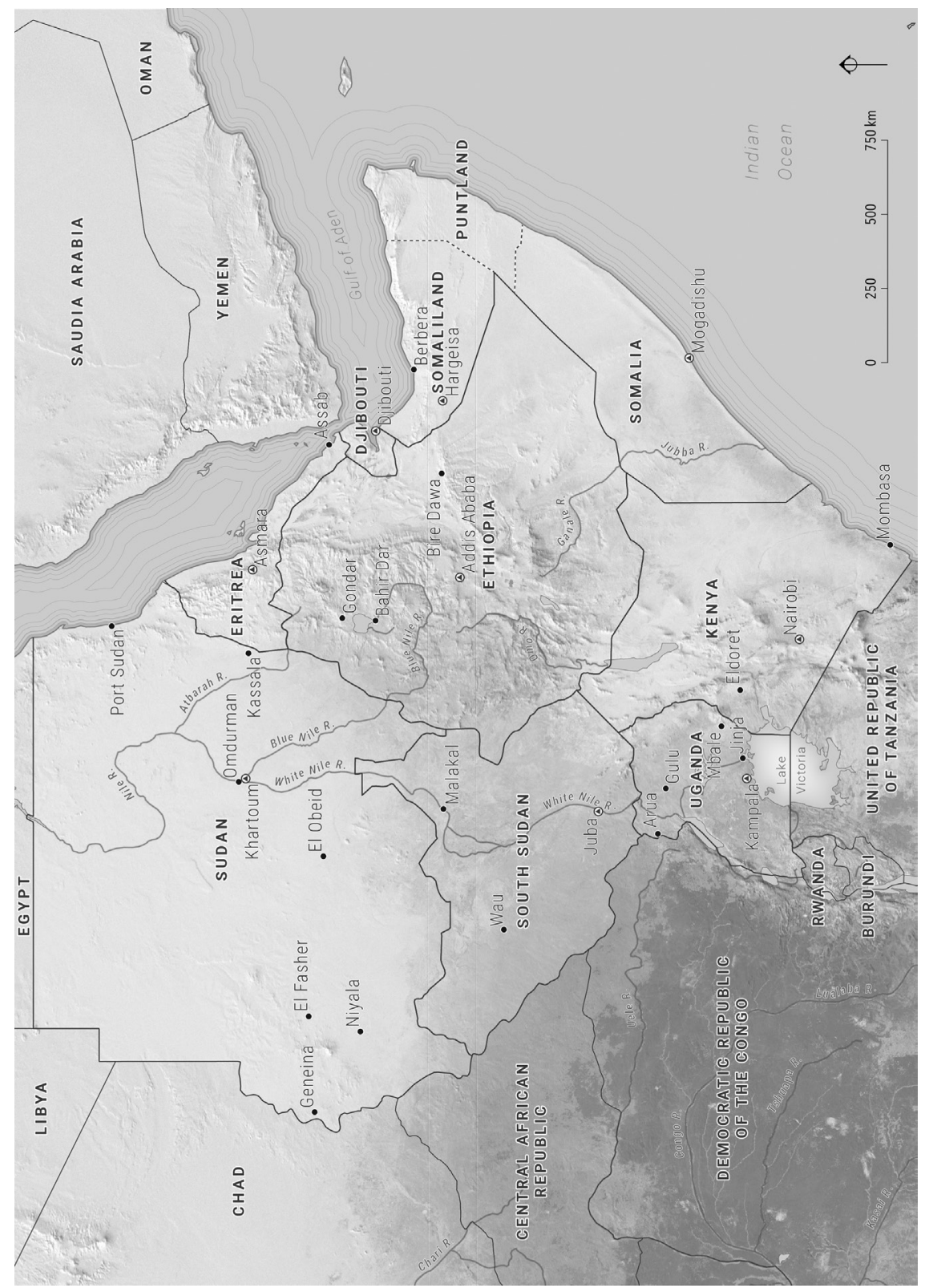

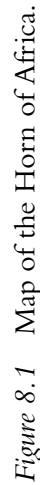


of urbanization. Although several of these countries-most notably Ethiopia, Kenya, and Uganda-have enjoyed strong economic growth rates in recent years, most of the economic benefits are concentrated in a few of the region's major urban centers. Urban unemployment is high.

Tens of millions of people live in remote areas more or less beyond the reach of state authority, which leads to informal or hybrid governance arrangements, such as local protection forces, protection rackets, and tribal or clan customary authorities. Where governments are functional, some are beset by high levels of corruption. Somalia, South Sudan, Sudan, and Yemen are ranked among the six most corrupt governments in the world. ${ }^{3}$

States in the Horn generally feature center-periphery dynamics, in which a core region comprising the capital and economically valuable land is the center of political attention and services, while remote peripheral or border areas have been marginalized, with little infrastructure and basic services. This has created grievances in some peripheral communities that armed movements exploit. In Ethiopia, Eritrea, and Kenya, core-periphery dynamics partially correspond to religious divisions, with Muslim populations concentrated in peripheral zones. Armed groups, including terrorists, have exploited the region's hinterlands and now pose serious security threats at both the national and global levels.

The formal security sector is often responsible for predation on the citizenry rather than a source of protection and rule of law. ${ }^{4}$ In some cases, security forces are controlled by a dominant ethnic group and hence feared by other groups. ${ }^{5}$ In other cases, security forces are unpaid or irregularly paid, so they prey on local populations as a source of livelihood. These dynamics reduce the ability of the state to provide protection, security, and rule of law and can create complications for external actors engaged in support to regional security forces. ${ }^{6}$

Across the entire region, national and local politics are dominated by ethno-politics. Many governments reflect a form of ethno-hegemony, with one empowered ethnic group using control of the state to advance its elite's political and economic interests. Where multi-party democracy exists, parties tend to be strongly associated with an ethnic group, reducing elections to a form of ethnic census. Where political decentralization has been instituted, sub-national states or counties have been drawn more or less along ethnic or tribal lines. ${ }^{7}$

Nationalist movements and sentiments exist but are generally not as strong as affiliation to sub-national identity. Clannism has been particularly persistent and divisive in Somalia, and even al-Shabaab-which has been a vocal critic of clannism and is the political actor most committed to transcending clan-has failed to overcome it. ${ }^{8}$

Few borders in the region are actively patrolled. As a result, movement of goods, people, weapons, and contraband across borders is common, as is the spillover from violent conflicts. Al-Shabaab, for example, has exploited the poorly policed Kenya-Somalia border zone. The waters of the Gulf of Aden in the northern Horn do not serve as a barrier but instead are a maritime highway with ample movement of people, livestock, and goods across to Yemen, which is deeply enmeshed in the commercial economy of the Horn.

The Horn has been host to some of the world's costliest and longest-running wars. Sudan's civil war lasted several decades and cost an estimated two million lives. The civil war that erupted in South Sudan in December 2013 has led to the deaths of somewhere between 50,000 to 300,000 people and displaced over one million. ${ }^{9}$ The Somali civil war of 1991-1992 triggered a famine that cost 250,000 lives and produced a million refugees. War between Eritrea and Ethiopia in 1998-2000 led to 100,000 lives lost. ${ }^{10}$ Many other zones of the region suffer from chronic low-intensity warfare and flare-ups of communal violence.

Somali nationalists have long sought to unify all Somalis into a single nation-state and hence have rejected the colonially imposed borders with Kenya and Ethiopia, as ethnic Somalis inhabit most of eastern Ethiopia and northern Kenya, as well as half of Djibouti. These irredentist claims led to the Ogaden War of 1977-1978 between Somalia and Ethiopia, a war Somalia lost.

Today, the irredentist agenda is weak, but it can still be invoked to good effect by Somali nationalists and Islamo-nationalists and is an enduring preoccupation for the Ethiopian government. This has been a major 
factor in the long history of distrust and animosity between Ethiopia and Somalia, a tension that is likely to endure despite much improved relations between the two countries since 2017.

Al-Shabaab, which became an official al-Qaida affiliate in February 2012, remains the most dangerous terrorist group operating in the Horn. It continues to organize major terrorist attacks on both soft and hard targets in Somalia and the wider region. Most of its attacks outside Somalia have been in Kenya, but it has also successfully executed terrorist operations in Uganda and Djibouti, has links to violent terrorist networks in Tanzania, and has sought unsuccessfully to wage a war of terror on Ethiopia. ${ }^{11}$

\section{Somalia overview}

In Somalia, multiple clan liberation movements led to the fall of the Siad Barre regime in January 1991 and the collapse of the state. Somalia remained without a functional central government for 22 years. The civil war of 1991-1992 destroyed the capital Mogadishu, and the economy of plunder that ensued triggered a massive famine. A U.S.-led multinational peace enforcement effort, Operation Restore Hope, began in December 1992, and it immediately imposed some stability and ended the famine. Yet attempts to revive the central government failed.

A Mogadishu warlord, General Aideed, directed an attack on United Nations peacekeepers, and a fourmonth effort led by U.S. Special Operations Forces to capture Aideed culminated in a bloody raid in 1993 known as the Battle of Mogadishu, or Black Hawk Down, in which 18 U.S. troops and an estimated 500 Somalis were killed. The peace operation failed, and the United Nations withdrew in $1995 .{ }^{12}$

In the north, a breakaway region, Somaliland, declared independence from Somalia in May 1991 and gradually built up an internationally unrecognized, but effective, government. Somaliland has since been a zone of relative peace, security, and economic recovery in the eastern Horn.

Efforts to negotiate a revived state in Somalia succeeded in 2004 with the declaration of the Transitional Federal Government led by President Abdullahi Yusuf of the Majerteen/Darood clan. Yet armed groups associated with Hawiye clans in Mogadishu never accepted the Transitional Federal Government, and the governing body was unable to relocate to the capital from the southwestern town of Baidoa.

In 2006, the Islamic Courts Union (ICU), a broad umbrella group of Sharia (Islamic law) courts, came into conflict with U.S.-backed militias in Mogadishu. In June 2006, the ICU consolidated control over all of Mogadishu and quickly expanded its authority across most of southern Somalia in an attempt to govern.

Somalis largely welcomed the peace and security provided by the ICU, but it was short lived. The ICU's main source of military strength was a small but disciplined set of Islamist fighters, some ex-mujahidin veterans from the war against the Soviets in Afghanistan. These committed fighters would later be called al-Shabaab. ${ }^{13}$ Hardliners in that group pushed the ICU into confrontation with neighboring Ethiopia, and Ethiopia launched a cross-border offensive in December 2006, quickly crushing the ICU and forcing its leaders to flee to Eritrea. ${ }^{14}$

The Ethiopian military occupation of Mogadishu prompted armed resistance. Al-Shabaab regrouped and emerged as the lead faction in the insurgency. It succeeded in retaking most of southern Somalia and Mogadishu in 2007 and 2008, a period of destructive insurgency and counterinsurgency violence. AlShabaab was significantly more radical than the ICU and had direct ties to al-Qaida, to which its leaders pledged loyalty. The Ethiopian intervention was intended to quash an emerging Islamist threat on its borders, but its actions ended up producing the opposite effect. ${ }^{15}$

Ethiopia withdrew from Mogadishu in early 2009, and a large African Union peacekeeping force known as the African Union Mission in Somalia (AMISOM), composed mainly of Ugandan and Burundian troops, replaced the Ethiopian contingent. From 2009-2012, a violent stalemate ensued. The Transitional Federal Government moved back to the capital from Baidoa but remained a failed and corrupt government with virtually no capacity but protected by AMISOM. 
In 2012, under international pressure, Somalia held indirect elections that produced a post-transitional government called the Federal Government of Somalia (FGS) led by President Hassan Sheikh Mohamud. For a short period, optimism reigned. ${ }^{16}$ Somalis had public confidence in the new government, and alShabaab weakened and withdrew from major cities. Security improved, and Somali investments in business and real estate increased in the capital. The international community threw its full support behind the FGS and aid agencies, and diplomatic missions relocated from Nairobi, Kenya, to the large, protected Mogadishu International Airport zone.

Between 2013 and 2016, the situation deteriorated. Al-Shabaab regrouped yet again and began launching frequent, highly destructive terrorist attacks on soft and hard targets in Somalia and Kenya. The FGS was paralyzed by political in-fighting and high levels of corruption. Regional states such as Jubaland and South West State formed to advance the nascent federal system and became modestly functional as administrations.

In early 2017, indirect elections produced a new bi-cameral parliament and the selection of President Mohamed Abdullahi Mohamed as the new head of state. AMISOM troop-contributing countries announced their intent to begin withdrawing forces starting in 2018, adding urgency to the need to build up the capacity of the weak and clan-riven Somali National Army.

\section{6-2013: al-Shabaab's rise and fall}

Al-Shabaab began as a small circle of committed Somali jihadis who served as police in two of 14 Sharia courts in Mogadishu in or around 2002. A few of these jihadis had returned from Afghanistan as veteran mujahidin and maintained ties to al-Qaida's core organization and the East Africa al-Qaida cell in Kenya. They first came to the attention of the outside world through a string of political assassinations of exintelligence and military officers in Mogadishu in what was described as a "dirty war." 17

They also provided safe haven to a small number of East Africa al-Qaida figures who moved in and out of Mogadishu, prompting the U.S. government to partner with local militias in an attempt to apprehend the East Africa al-Qaida cell members. Although al-Shabaab numbered only a few hundred fighters at the time, it was disciplined, well-trained, and decisive in the ICU's rapid military victory in Mogadishu in 2006.

Al-Shabaab suffered heavy losses in the initial Ethiopian military intervention in southern Somalia in 2006, but it had regrouped by April 2007 and emerged as the lead armed resistance against the Ethiopian army and the Transitional Federal Government. It quickly attracted broad support from Somalis at home and abroad, even from those who despised its radicalism. It was widely viewed by Somalis as a legitimate form of resistance to an illegal foreign occupation.

Thousands of Somalis joined the group, and many hundreds of Somali youth in the diaspora, including Somali-Americans, traveled to Somalia to join as well. Other Somalis from the diaspora engaged in fundraising for al-Shabaab. ${ }^{18}$

During the 2007-2012 period, al-Shabaab paid its fighters a regular salary, which served as a major incentive to join because most militias were unpaid in Somalia. It generated funding from contributions, taxes, and especially revenues from control of seaports such as Kismayo, where lucrative charcoal exports contributed substantially to what the United Nations estimated was the group's total annual budget of $\$ 70-\$ 100$ million per year. ${ }^{19}$

By early 2008, al-Shabaab succeeded in retaking almost all of southern Somalia and controlled most of the capital Mogadishu. This was the group's high-water mark.

From the outset, al-Shabaab has been attentive to public relations, focusing on four main targets of influence: Somalis in country, Somalis in the diaspora, the global Islamic umma, and al-Shabaab's enemies.

In country, the group relies primarily on radio broadcasts, sermons, and speeches delivered to assemblies in its area of control. For external public relations-which is directed at Somalis in the diaspora, the global 
Islamic umma, and the group's non-Somali enemies - the group has relied on a combination of internet chat rooms, videos, affiliated online news sites, and Twitter. Its periodic videos were initially crude and amateurish in 2007-2008 but have since become significantly more sophisticated. Its real-time use of Twitter to mock Kenyan security forces and implore Muslims worldwide to take up the call to jihad during its attack on the Nairobi Westgate Mall in 2013 revived its reputation in global jihadi circles. ${ }^{20}$

During the 2007-2012 period, al-Shabaab always framed its objectives more by what the group opposed rather than promoting a vision for the future. For example, it opposed Ethiopian and then African Union peacekeepers in Somalia and sought to drive them out; it opposed the Somali transitional government, regardless of who held power in it; and it opposed any and all behavior and actors deemed un-Islamic.

Its strategic goals remained the subject of internal dispute. Some of its leaders embraced al-Qaida's vision of an eventual global Islamic caliphate, but the majority of the group's members and leaders were focused on an Islamo-nationalist agenda: the formation of an Islamic state in Somali-inhabited areas of the Horn, including northern Kenya and eastern Ethiopia. ${ }^{21}$

From 2009-2012, al-Shabaab entered a period of stalemate and decline. Designation of the group as a terrorist organization by the United States and other major governments had a chilling effect on diaspora support and fundraising. Al-Shabaab's rule in areas it controlled and its interpretations of Sharia were harsh and unpopular. Its use of suicide bombers against civilian targets shocked and angered Somalis, and its seeming indifference to heavy casualties sustained by its own young fighters led to blowback from angry clans.

Recruitment during this period was initially voluntary, but reports that al-Shabaab was forcibly conscripting boys and young men emerged in 2009. ${ }^{22}$ In some cases, they pressured and coerced families into providing a young male as a fighter in lieu of taxes-a practice that has intensified in recent years. In other cases, they went to schools to conscript boys.

The costs of association with al-Shabaab mounted, causing leaders of two large and powerful clans - the Haber Gedir Ayr and the Ogaden - to break with the group. ${ }^{23}$ The Ayr shifted support to an armed Sufi Muslim group, called Ahlu Sunnah Wal Jama, to oppose al-Shabaab, while the Ogaden Ras Kamboni militia flipped to an alliance with Ethiopia and Kenya and eventually captured Kismayo seaport from alShabaab in 2013 - an important strategic victory. Once al-Shabaab lost Kismayo seaport, it relied more aggressively on extortion of monthly "taxes" from Somali citizens and taxes collected at checkpoints on commercial traffic. ${ }^{24}$

Al-Shabaab was unable to fight against the heavy armor of AMISOM forces and found it difficult to hold territory in conventional battles. The group also struggled with mounting internal divisions over clan, tactics, goals, and links to al-Qaida. ${ }^{25}$ Finally, al-Shabaab's standing in Somalia was tarnished when it blocked food aid into areas it controlled — part of the group's campaign against international aid groupsduring the 2011 famine that claimed 260,000 lives. ${ }^{26}$

The regional response to al-Shabaab's ascent has been robust but not always effective. Ethiopia's initial two-year military occupation of southern Somalia in 2007-2008 succeeded in driving the ICU out of power, but al-Shabaab regrouped in the countryside and assumed the role as the lead resistance movement against the Ethiopian occupation. The Ethiopian intervention ended up as a quagmire and handed al-Shabaab an easy rallying point to mobilize anti-Ethiopian support among Somalis. In fact, by 2008, alShabaab had already retaken most of southern Somalia and much of the capital Mogadishu.

Yet in 2011, under pressure from AMISOM, al-Shabaab withdrew from most of Mogadishu and other towns it had controlled, retreating into the countryside. It shifted tactics, opting for a campaign of asymmetric warfare featuring greater use of hit-and-run ambushes, remote-controlled improvised explosive devices, and assassinations. The selection of a new, post-transitional government in August 2012 - the FGS - was greeted with significant public support and expectations, draining support from al-Shabaab.

By the summer of 2013, tensions inside al-Shabaab exploded in a bloody purge that left a number of top figures dead, triggered an exodus of most foreign fighters out of Somalia, and consolidated 
power into the hands of hardliner Ahmed Godane. ${ }^{27}$ Many observers felt that al-Shabaab was spiraling into terminal decline.

\section{3-2020: al-Shabaab remains resilient}

Despite the series of disastrous setbacks in 2011-2013, al-Shabaab remained resilient by adjusting its tactics, reinventing itself, and thus reviving its fortunes. Today, al-Shabaab still struggles with profound problems, and some of its tactics can be construed as signs of weakness or desperation rather than strength, but it has coped with its vulnerabilities and remains a dangerous terrorist threat to both Somalia and the wider region. $^{28}$

Al-Shabaab's revival can be attributed to a combination of key factors: redirection, asymmetric warfare tactics, fear and extortion, collusion, exploitation of grievances, and a strategy of stalemate.

\section{Redirection}

Faced with setbacks and fading fortunes inside Somalia, al-Shabaab redirected its violence at Kenya. For years, the group had used Kenya for recruitment, fundraising, and transit but had been restrained in its use of terrorist attacks on Kenyan territory. Kenya's decision to launch a military offensive in southern Somalia to drive al-Shabaab out of the border area in October 2011 angered and humiliated many Somalis and gave al-Shabaab an easy pretext for expanding its campaign of violence against Somalia's neighbor.

Its first major terrorist attack in Kenya, targeting the popular Westgate Mall in Nairobi in September 2013, was devastatingly successful. The terrorist operation dealt a heavy blow to Kenya: it exposed the country's inept and corrupt security forces, made al-Shabaab the top news story in the global media for a week, and recast al-Shabaab from a defeated insurgency to a major jihadi threat.

The attack also predictably baited the Kenyan government into launching a heavy-handed and indiscriminate law enforcement response that appeared to target all Somalis in Kenya-whether refugees, visitors, or Kenyan citizens. The Kenyan mass detentions and abusive police behavior angered Somali Kenyans and risked pushing some into al-Shabaab's arms. ${ }^{29}$

Al-Shabaab followed the Westgate Mall attack with a series of terrorist operations in Kenya, all focused on soft civilian targets and designed to drive a wedge between Kenyan Muslims and Christians that alShabaab hoped to exploit. Its tactic was to spare Muslims and massacre Christians. Al-Shabaab's propaganda videos called the attacks retribution for infidel invasion and occupation of Muslim lands, striking a chord with some Somalis. It increasingly drew on Somali and other recruits from within Kenyan society, leading many to conclude that its jihadi violence in Kenya was no longer only a cross-border affair but had become an internal Kenyan problem. ${ }^{30}$

In April 2015, al-Shabaab launched a bloody and brutal attack on Garissa University in the Somaliinhabited portion of northeast Kenya. The attack amounted to a cold-blooded massacre: al-Shabaab killed 148 students, picking out the Christians for execution while allowing Muslims to go free. The attack was so shocking that it may have worked against al-Shabaab by producing a backlash in Somali Kenyan society.

Improved Kenyan security and intelligence, supported by external allies, has also made Kenya a more difficult environment for al-Shabaab. Terrorist attacks in Kenya dropped off dramatically in 2016. By then, however, al-Shabaab had already shifted its energies back into Somalia.

\section{Asymmetric warfare tactics}

Al-Shabaab's tactical retreat from holding major towns and neighborhoods in Mogadishu allowed it to focus exclusively on asymmetric warfare, which played to its strengths. Guerrilla warfare has been implemented in two ways, both equally effective. 
One type is low risk, small-scale hit-and-run attacks, which include ambushes on convoys, remotecontrolled improvised explosive devices, grenade or mortar attacks, and assassinations. Al-Shabaab launches several of these on a daily basis. They are designed to harass, frighten, and demoralize Somalis in the FGS and AMISOM and make them engage in costly risk-averse countermeasures. AMISOM forces, for example, have been accused of indiscriminate firing on civilians, leading to significant civilian casualties and local anger.

The second type are more complex terrorist attacks aimed at high-visibility, hard targets such as government installations, AMISOM bases, Mogadishu International Airport, or heavily secured hotels frequented by Somali political figures and international diplomats. They typically involve a car bomb that destroys the entry gate, followed either by a vehicle filled with suicide fighters who swarm into the compound or a larger truck bomb that is detonated inside the compound.

Both variations of the model are difficult to counter and have resulted in major attacks with high casualties. In a few cases, where attacks target AMISOM forward bases, casualty levels have exceeded 100 people. ${ }^{31}$ The tactic requires capacity in bombmaking, which al-Shabaab possesses, and a ready supply of vehicle drivers and fighters who are prepared to die as martyrs. The latter is a potential weakness for the group, and evidence exists that al-Shabaab has resorted to coercing or duping young men into the role.

Not all of these complex terror attacks succeed, but enough are successful, and they have had a major impact on morale and security protocols for AMISOM, the FGS, and the international community. The expansive Mogadishu International Airport complex - where nearly all of the United Nations staff, AMISOM officers, embassies, contractors, military trainers, and other international visitors are concentratedis heavily fortified and bunkered.

The total loss of life in AMISOM is unknown due to a lack of transparency by troop-contributing countries on an issue they consider politically sensitive, but it is high and has produced public outcries in AMISOM member states. AMISOM's response to these attacks has been to prioritize force protection, including withdrawal from forward bases. AMISOM has been frustrated by Somali army clannism, collusion with al-Shabaab, failure to hold recovered space, and predatory behavior toward local communities, some of whom turn to al-Shabaab for protection.

Since 2014, AMISOM has ceased launching offensives against al-Shabaab. AMISOM is not fit for purpose to pursue a mobile, decentralized al-Shabaab in remote rural areas. ${ }^{32}$ This has allowed al-Shabaab to reenter villages and towns it had lost without a shot.

\section{Fear and extortion}

Al-Shabaab's most powerful tool is the Amniyat, a surveillance and intelligence network with operational capacity that has deep reach into all Somali institutions, including the Somali government, the Somali National Army, and many foreign aid agencies. The Amniyat's penetration of the government and security sector makes it difficult for Somali security forces to launch an operation without al-Shabaab having advance knowledge, which gives the group a significant advantage planning attacks.

The Amniyat tracks the employment and income of Somalis in its areas of operations and facilitates alShabaab's systematic taxation or extortion of money from citizens and businesses. Recent evidence exposed the fact that al-Shabaab's ability to extort money from Somalis extends into parts of northern Kenya. ${ }^{33}$

Those who refuse to pay are threatened with assassination and their businesses bombed. The Amniyat is responsible for planning and executing suicide bombings as well as hit-and-run attacks. ${ }^{34}$ The Amniyat instills fear, discourages Somalis from cooperating with the FGS and AMISOM, and pressures Somalis to collude with it. Its organization and tactics mimic those of an effective mafia. It is entirely possible that portions of the Amniyat network could outlast al-Shabaab itself and morph into a criminal extortion racket. 


\section{Collusion}

Somalis have become experts at risk management, and one means of managing risk in an uncertain political environment is to keep doors open to all sides. Al-Shabaab exploits this impulse and has forged a dense set of relations across Somali society involving collusion with al-Shabaab. Collusion even extends to individuals in the FGS and Somali army and touches most businesses and international agencies, whether their top officials are aware of it or not. ${ }^{35}$

\section{Exploitation of grievances}

Al-Shabaab recruits from across all Somali clans, but it has become adept at understanding and exploiting grievances of clans that have been marginalized in national or regional politics or preyed upon by dominant clans. These aggrieved clans turn to al-Shabaab as a tactical ally, as a means of resisting the Somali army or improving their bargaining position with regional or national authorities. The extent of grievances in Somalia, whether justified or not, has given al-Shabaab ample traction in some lineages, although the group has not been able to truly transcend the pervasive clannism in Somali society. The woeful performance and public unhappiness with the FGS since 2012 has been a gift to al-Shabaab, allowing it to contrast the corruption, clannishness, and paralysis of the government with its own more competent and clean record of local governance.

\section{Stalemate strategy}

Since 2011, al-Shabaab appears to be content to play for a draw in Somalia while expanding its recruitment and operational reach in East Africa. In Somalia, its strategy is to block progress by the FGS, demoralize Somali and international supporters of the FGS, consolidate its extortion network to collect taxes on people and businesses, and inflict enough losses on AMISOM to prompt it to withdraw. Al-Shabaab believes that time is on its side and that eventually a war of attrition will result in an AMISOM withdrawal and new opportunities for al-Shabaab to exploit.

AMISOM's troop-contributing governments have declared their intent to gradually withdraw from Somalia. While this process is likely to take years and may not result in a complete redeployment (some peacekeepers may stay on in a support role to the Somali National Army), the prospect of an eventual AMISOM withdrawal will produce a seismic change in the overall security environment in southern Somalia. If the Somali army is not able to insert itself and assume its proper role, the security vacuum that results will be exploited by al-Shabaab, and the entire FGS could be at risk.

Al-Shabaab's wider regional ambitions, especially in Kenya, have involved a much more aggressive strategy involving terrorist attacks aimed at high-visibility civilian sites and expanded recruitment across a large swathe of Kenyan society.

Despite its impressive revival in Somalia since 2012, al-Shabaab continues to face problems that continually risk plunging the group into crisis. Its tactics, especially suicide car bombings and assassinations, are deeply unpopular with Somalis and have shrunk the group's public support. The group's vigorous taxation is increasingly viewed as extortion and is being met in some locations by armed clan resistance. Al-Shabaab has been put on the defensive in the Lower Shabelle region as a result of offensives by a combination of the Somali army, AMISOM, and clan militias backed by U.S. drone attacks.

The group has lost a number of top officials - including its leader Ahmed Godane in 2014- to American airstrikes. ${ }^{36}$ Its current leadership has faced defections by important figures. The group is also facing a mounting challenge from groups professing allegiance to the Islamic State. In some regions of Somalia, violent campaigns between al-Shabaab and the Islamic State resemble mafia turf wars over control of taxation of local businesses. 


\section{Al-Shabaab's future}

Al-Shabaab has demonstrated tremendous resilience in the face of serious external pressures and internal crises. If past performance is an indication of future trends, the group is likely to continue to be a major armed spoiler in the near to mid-term. It faces a weak, dysfunctional, and penetrated Somali army; a Somali government of questionable legitimacy and weak capacity; foreign peacekeepers with stated intentions to begin to withdraw in 2021; and a fearful, risk-averse Somali population. Its asymmetric military tactics allow it to choose the time and place of attacks and armed engagements, and its Amniyat network affords it superior intelligence. For all of its weaknesses, it faces relatively little resistance. The most dangerous immediate threat to the group at present is U.S. military operations against its leaders.

Continued stalemate is the most likely scenario in the coming years. Al-Shabaab possesses ample capacity to harass the FGS and launch terrorist attacks but not necessarily the ability or even the desire to hold major cities and make itself a fixed target of external counterterrorism strikes.

If AMISOM withdraws from Somalia completely, it is possible that al-Shabaab will overrun the Somali army and take most or all of Mogadishu, leading to the fall of the FGS. This worst-case scenario would pose enormous challenges for the United States and regional states and would likely precipitate a mass exodus of Somali refugees.

Somali civic and political figures, and some external diplomats and advocacy groups, frequently raise the prospect of a negotiated settlement between al-Shabaab and the FGS. Quiet efforts have been made for years but have not borne fruit. There are extensive lines of communication between al-Shabaab and the FGS as a result of clan affiliations that bridge the two, so the problem is not a lack of good offices.

For now, this scenario seems unlikely, as al-Shabaab believes time is on its side, and key external actors, most notably Ethiopia and Kenya, and quite possibly the U.S. government, would seek to veto any negotiations. Yet variations on this scenario are plausible. If strikes on al-Shabaab continue to weaken it and worsen internal fissures, the leadership could look to strike a deal, or breakaway factions could defect.

A final scenario is an al-Shabaab collapse. If the FGS administration makes real progress in combating corruption, professionalizing the Somali army, and making governance more inclusive and effective, al-Shabaab will find itself with little support among war-weary Somalis. Its many fault lines make it quite susceptible to another round of internal feuding and defections. In this event, rump portions of al-Shabaab could degenerate into a dangerous mafia extortion racket that would take time to marginalize.

Overall, al-Shabaab is likely to remain a significant and chronic threat to the FGS, regional member states in Somalia, regional states in the Horn of Africa, and Western and international agencies working in the Horn. Soft targets such as hotels and shopping malls will continue to be vulnerable to complex suicide bombings in the Horn and in Somalia. Despite its many internal weaknesses, al-Shabaab is able to conduct terrorist attacks with relative ease, at low cost, and with little risk. It has also proven effective at exploiting local grievances to secure tactical alliances and recruits. The enduring threat posed by al-Shabaab ensures that Ethiopia and Kenya will remain deeply involved in Somalia for the foreseeable future, as will other external actors concerned about the wider security threats posed by the group.

\section{Notes}

1 Terje Ostebo and Patrick Desplat, eds., Muslim Ethiopia: The Christian Legacy, Identity Politics, and Islamic Reformism (New York: Palgrave MacMillan, 2013); Haggai Erlich, Islam and Christianity in the Horn of Africa: Somalia, Ethiopia, Sudan (Boulder: Lynne Rienner Press, 2010).

2 There is no uniform definition of which states constitute the Horn of Africa region. Some studies limit the Horn to Ethiopia, Eritrea, Somalia, and Djibouti. Others encompass the "Greater Horn of Africa" and include Kenya, Uganda, Sudan, South Sudan, and Yemen. 
3 Transparency International, Corruption Perceptions Index 2016 (Berlin: Transparency International, 2017).

4 Bureau of Democracy, Human Rights, and Labor, 2019 Country Reports on Human Rights Practices: Somalia (Washington, DC: U.S. Department of State, 2019).

5 “Shortages, Clan Rivalries Weaken Somalia's New Army," The New Humanitarian, May 28, 2014, www.thenewhumanitarian.org/news/2014/05/28/shortages-clan-rivalries-weaken-somalia-s-new-army; Clemence Pinaud, "South Sudan: Civil War, Predation, and the Making of a Military Aristocracy," African Affairs 113, no. 451 (2014): 192-211.

6 Paul Williams, Understanding US Policy in Somalia: Current Challenges and Future Options (London: Chatham House, 2020).

7 International Crisis Group, Ethiopia: Ethnic Federalism and its Discontents (Brussels: International Crisis Group, 2009).

8 Stig Hansen, “An In-Depth Look at Al-Shabab's Internal Divisions," CTC Sentinel 7, no. 2 (2014): 9-12.

9 "South Sudan Is Dying, and Nobody Is Counting," News24, March 11, 2016, www.news24.com/news24/africa/ news/south-sudan-is-dying-and-nobody-is-counting-20160311-4.

10 Bronwyn Bruton, "Ethiopia and Eritrea Have a Common Enemy," Foreign Policy, July 12, 2018, https://foreignpolicy.com/2018/07/12/ethiopia-and-eritrea-have-a-common-enemy-abiy-ahmed-isaias-afwerki-badme-peacetplf-eprdf/.

11 Matt Bryden and Premdeep Bahra, "East Africa's Terrorist Triple Helix: The Dusit Hotel Attack and Historical Evolution of the Jihadi Threat," CTC Sentinel 12, no. 6 (2019): 1-11; International Crisis Group, Al-Shabaab Five Years Africa Westgate: Still a Menace in East Africa (Brussels: International Crisis Group, 2018).

12 Todd South, "The Battle of Mogadishu 25 Years Later," Army Times, October 2, 2018, www.armytimes.com/ news/your-army/2018/10/02/the-battle-of-mogadishu-25-years-later-how-the-fateful-fight-changed-combatoperations/.

13 International Crisis Group, Somalia's Islamists (Brussels: International Crisis Group, 2005).

14 Ken Menkhaus, "The Crisis in Somalia: Tragedy in Five Acts," African Affairs 106, no. 424 (2007): 357-390.

15 Ken Menkhaus, "Somalia: 'They Created a Desert and Called It Peace (Building)',' Review of African Political Economy 36, no. 120 (2009): 223-233.

16 Laura Hammond, "Somalia Rising: Things Are Starting to Change for the World's Longest Failed State," Journal of Eastern African Studies 7, no. 1 (2013): 183-193; International Crisis Group, Somalia: An Opportunity That Should Not Be Missed (Brussels: International Crisis Group, 2012).

17 International Crisis Group, Counter-Terrorism in Somalia: Losing Hearts and Minds? (Brussels: International Crisis Group, 2005).

18 Stig Hansen, Al-Shabaab in Somalia: The History and Ideology of a Militant Islamist Group (New York: Oxford University Press, 2013).

19 Monitoring Group on Somalia and Eritrea, Report of the Monitoring Group on Somalia and Eritrea Pursuant to UN Security Council 1916 (2010) (New York: United Nations, 2011), 27.

20 Ken Menkhaus, "Al-Shabaab and Social Media: A Double-Edged Sword," The Brown Journal of World Affairs 20, no. 2 (2014): 309-327.

21 International Crisis Group, Somalia's Divided Islamists (Brussels: International Crisis Group, 2010).

22 Human Rights Watch, No Place for Children: Child Recruitment, Forced Marriage, and Attacks on Schools in Somalia (New York: Human Rights Watch, 2012).

23 Not all members of these clans supported al-Shabaab before 2008, and not all supporters from these clans defected, but as a group, the clans shifted positions.

24 Personal interviews, Kismayo, Somalia, December 2016.

25 Christopher Anzalone, "Al-Shabab's Tactical and Media Strategies in the Wake of Its Battlefield Setbacks," CTC Sentinel 6, no. 3 (2013): 14.

26 Ken Menkhaus, “No Access: Critical Bottlenecks in the 2011 Somali Famine," Global Food Security 1, no. 1 (2012): 29-35.

27 Matt Bryden, The Re-invention of Al Shabaab: Strategy of Choice or Necessity? (Washington, DC: Center for Strategic and International Studies, 2014).

28 Matt Bryden, The Decline and Fall of al-Shabaab? Think Again (Minneapolis: Sahan, 2015).

29 David M. Anderson and Jacob McKnight, "Kenya at War: Al-Shabaab and Its Enemies in Eastern Africa," African Affairs 114, no. 454 (2015).

30 Bryden, The Re-invention of Al Shabaab.

31 Harun Maruf and Dan Joseph, "No End in Sight for the Al-Shabaab Threat to Somalia," CTC Sentinel 11, no. 11 (2018): 16-20.

32 Paul Williams, Fighting for Peace in Somalia: A History and Analysis of the African Union Mission (AMISOM), 20072017 (New York: Oxford University Press, 2018). 
33 "Mandera Locals Warned Against Playing Tax to al-Shabaab," The Nation, October 21, 2016, https://nation.africa/ kenya/videos/news/mandera-locals-warned-against-paying-tax-to-al-shabaab-318982.

34 Bryden, The Re-Invention of Al Shabaab.

35 Ken Menkhaus, "Managing Risk in Ungoverned Space: Local and International Actors in Somalia," SAIS Review 36, no. 1 (2016): 109-120.

36 Helene Cooper, Eric Schmitt and Jeffrey Gettleman, "Strikes Killed Militant Chief in Somalia, U.S. Reports," New York Times, September 5, 2014, www.nytimes.com/2014/09/06/world/africa/somalia-shabab.html. 